ADELAIDE UMVERSITY CENTRE FOR THE PERFORMUNG ART'S - PRESENTS.
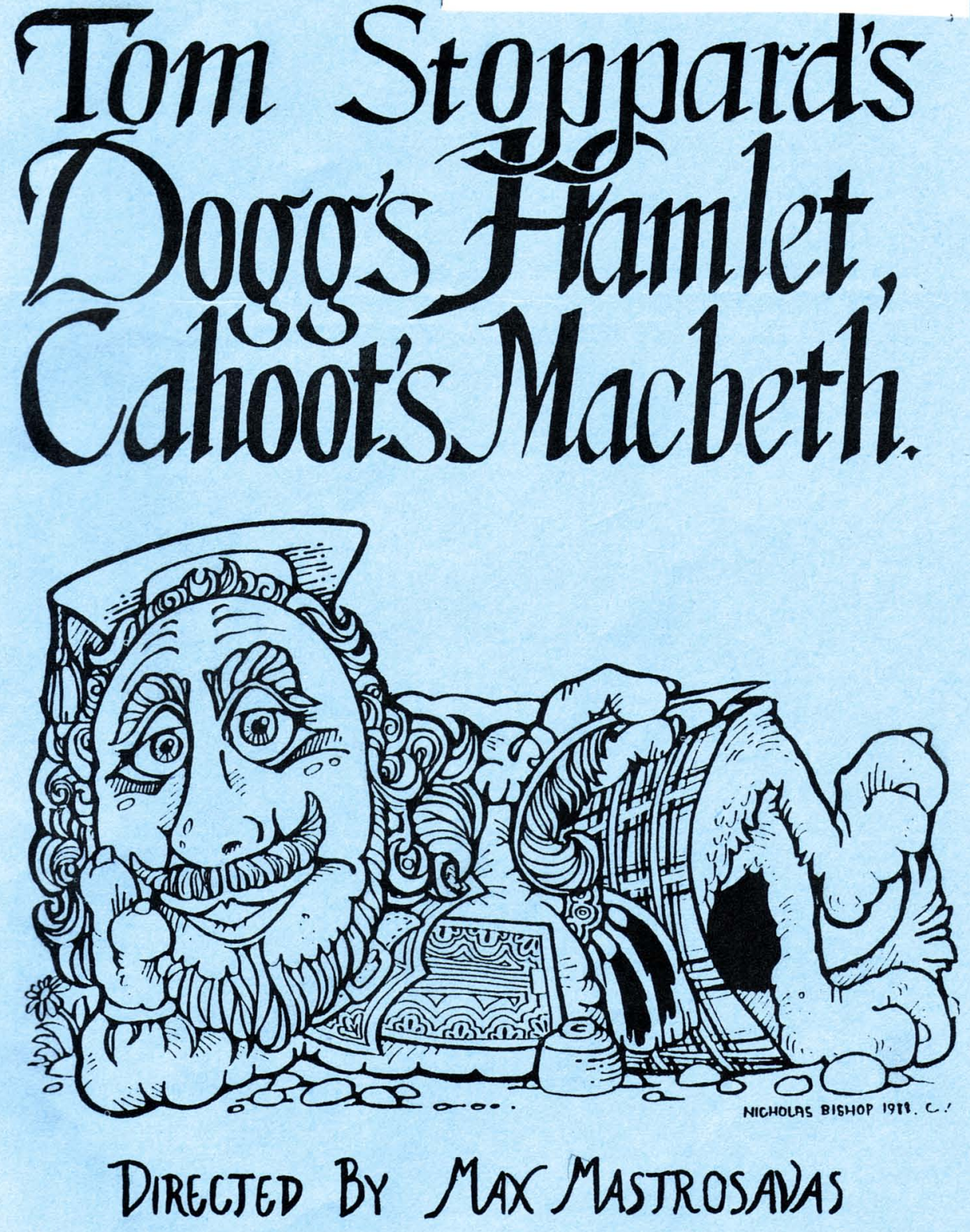

BY SPECML ARRANGEENENT WITH SAMUEL FRENCH (AUST) PJY. (TDD. 


\section{The Drama Department}

The existence of the Drama Department may appear to be a well kept secret to some of the wider community. Indeed, our headquarters, The Centre For the Performing Arts, is tucked away, out of sight in the old Medical Building. However, the Drama Students are a prominent minority, infusing a streak of creativity into the bastion of knowledge that is the Adelaide University. This is not to say that the Drama Department has the monopoly on creativity.

Theatre has long been a part of the life of the University. Many a student of earlier generations will recall the productions of the Theatre Guild, A.U.D.S. and Footlights. It was not until 1975, however, that Drama 1 was established as an academic subject. The aim of the course was to respond to the large student interest in the Dramatic Arts and to the corresponding increased awareness of the theatre within the community.

South Australia has always been a state in which the Dramatic Arts have flourished. Essential to this continuing development is the establishment of academic and creative drama courses within our Universities.

The two plays presented tonight are the result of many hours of work by all involved. The development of a production from the first reading to opening night is a complicated process, requiring a plethora of production skills, the people to impliment these and a mountain of enthusiasm. Hopefully, this year's Drama students have proved equal to the task.

We wish you an enjoyable evening's entertainment. 


\section{Dogos Jamlet.}

Those watching tonight's plays for the first time may well be bewildered by some of the strange language used. Indeed, some of the phrases used appear quite inane; "upside artichoke Leamington spa?" One would be tempted to think that Tom Stoppard, the man who brought us "Jumpers" and "Rosencrantz and Guildenstern Are Dead", had taken his passion for confusing the audience just a little too far.

In Dogg's Hamlet and Cahoot's Macbeth, Stoppard has created an entirely new language: Dogg. Dogg uses deceptively familiar English words but the rules surrounding their usage are different to those applied in English (for example "cube" means "thank you"). This is essentially an exercise in changing the rules of the language game. The language game is a game we are all taught, even before hide and seek. Can any of us claim to remember being taught the word "is"? We all learnt it from the way in which people around us used it. Language acquisition is primarily a contextual activity, based on imitation. Thus we learn the various rules and regulations of our native idiom. Meaning has no prior status, "a rose by any other name would smell as sweet".

Realization of the non-absolute nature of the meaning of words is not unique to stoppard. He, himself, acknowledges his indebtedness to Wittgenstein's Philosophical Investigations. "Dogg"s Hamlet" is derived directly from an example given in Wittgenstein's work, that of two builders giving each other instructions. To an independant observer, whether "plank" means plank, or whether it means "ready" is unknown.

A similar confusion permeates Dogg's Hamlet, where Dogg is confronted with modern and Shakespearean English (in the form of an almost nonsensical abridgement of Hamlet). The language game becomes a confused free for all, where the languages familiar to the audience become the language of the minority. Dogg is the dominant idiom. 


\section{Calloot's Macbeth.}

In Cahoot's Macbeth, Dogg becomes the language of the revolution. This is an unmistakably political play, based on the suppression of the Czechoslovakian theatre after the Communist take-over. It is dedicated to Pavel Kohout, a Czech playwright who established the Living Room Theatre as a way of avoiding the authorities. Cahoot's Macbeth begins with a short but coherent version of Macbeth, being performed in a private apartment. This is interupted by the authorities of the state, declaring it to be seditious. The performance can only go on when the actors learn Dogg, for it becomes incomprehensible to the policeman. Linguistic anarchy is equated with social revolt. By changing the rules of the language game, the actors free themselves from the oppression facing them.

It all sounds a bit complicated, but bear with us and we will assure you that we will provide you with a good night's entertainment, and you will all go home "cubing" each other for a lovely evening. PENNY WONG (Dramaturg)

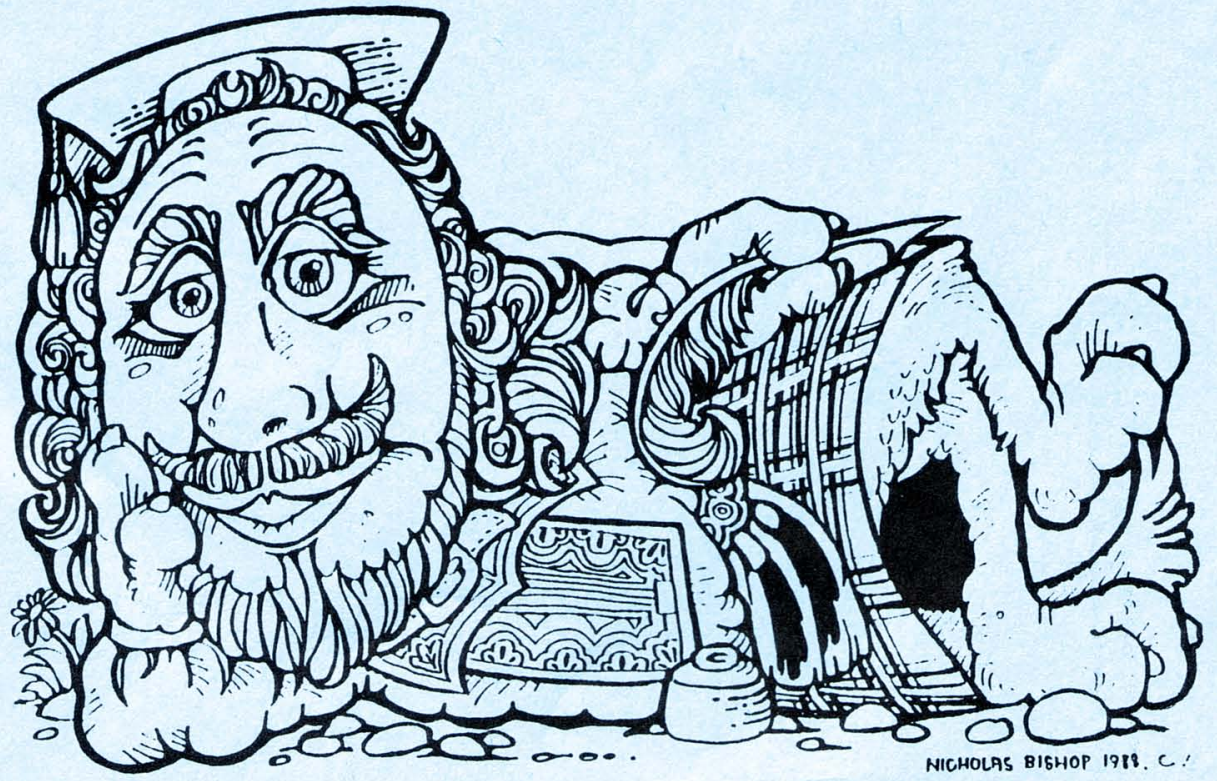




\section{Dogos Fformlet}

\section{Cast}

BAKER/FRANCISCO/HORATI0,.... Alex Champion ABEL/BARNARDO/MARCELLUS.... Dan Grieve CHARLIE/OPHELIA.......... David Mealor EASY................. Alan Hayward DOGG/SHAKESPEARE......... Nicholas Bishop MRS DOGG/GERTRUDE........ Cathy Adamek FOX MAJOR/HAMLET.......... Kelly Crimeen LADY.................. Cate Rogers CLAUDIUS................ Paul Moore GHOST/OSRIC............ Emma Mc Ewin POLONIUS................ Jayne Paramor GRAVEDIGGER............. Sally Sara LAERTES ............... Nicholas Garsden FORTINBRAS............. Tracey Grady MUSICIANS.... Anke Willems Timothy Schaffer (Clarinet) Jane Duncan Mardi Mc Connochie (Recorder) (Voice-Soprano) (Voice-Alto)

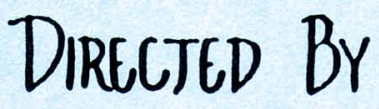

ASSISTANT DIRECTOR........ John Gill 


\section{Cahoot's Macbeth.}

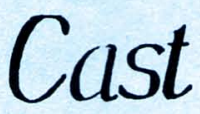

1sT WITCH.......... Dwina Noesbar

2ND WITCH.......... Elena Carapetis

3RD WITCH.......... Anke Willems

MACBETH.......... Chris Stevenson

BANQUO/CAHOOT...... Derek Schild

ROSS/LENNOX........ Mat Banks

LADY MACBETH....... Finola stokes

KING DUNCAN........ Guy wheal

MESSENGER........ John Wells

HOSTESS.......... Gina Tsikouras

MACDUFF.......... Caroline Mealor

MALCOLM.......... Connie Kosti

1st MURDERER...... Erica Sharplin

2ND MURDERER....... Belinda Lo vell

INSPECTOR......... Gregory Richards

BORIS............ Stephen Biggins

MAURICE.......... Glen Johns 


\section{Production Crew}

STAGE MANAGER........... Kathy Alley

ASSISTANT STAGE MANAGERS..... Jane Costessi

Kelli Jones

CHOREOGRAPHY............. Stephanie Arthur

PRODUC'TION CO-ORDINATOR...... DOnnamarie Mc Nulty

DRAMATURG............... Penny Wong

SET CREW...Nicholas Bishop Mike Black

Cathy Hill

Mary mline

Sally sara

Matt Banks

John Wells

Derek Schild

Frances Theile

Heidi stoll

PUBLICITY .. Merry Potter

Sheridan Smith

Emma Mc Ewin

Alex Champion

Paul Moore

Dwina Noesbar

Stephanie Arthur

Mardi Mc Connochie

Stephen Biggins

Erica Sharplin

Christina Puglia

Jane Duncan

Alison Wakefleld

Chris Manos

Timothy Schaffer

Gina Tsikouras

Elena Carapetis

Libby Angel

SOUND.......Bindi Baker

Chris Stevenson

Claire Hadley

With special thanks to Maddy Misirdjieff

COSTUME....Tracey Grady

Suzanne Hall

Kari Bienert

Cathy Adamek

David Mealor

PROPS.......Chris Rutherford

Diana Kempe

Edwina Swan
Susan Hynes

Jayne Hayes

Sara Lee Aufderheide

Kelly Crimeen

Libby Angel

Guy Wheal

Derek Schild

Alan Hayward 
PROMPTS.............. Chris Rutherford Edwina Swan Guy Wheal

FRONT OF HOUSE...Belinda Lovell Jayne Paramor Edwina Swan Chris Manos

LIGHTING ..........Alison Oakeshott Nicholas Garsden Melissa Goldsworthy Chris stevenson Caroline Mealor
Kathy Alley Libby Angel Derek Schild

Glen Johns Dan Grieve Derek Schild Guy Wheal

Holly Gardner Connie Kosti Finola stokes Irene Kushelev Mischa Kubancik

\section{PUPPET MAKERS}

AND : OPERATORS .....Lisa McDonald Jane Costessi

John We11s Jane Duncan

POSTER DESIGN......Nicholas Bishop

PRODUCTION PHOTOGRAPHY....Phil Heaton

\section{UNI RECORD SHOP}

- Records * Cassettes " compact discs *

- blank tapes *

Check out our specials on the above items throughout the year. We have extremely competitive prices.

- Popular - Classical - Jazz - etc. -

* We buy and sell secondhand rocdrds, cassettes, and compact discs.

- Imported L.P.'s

* Imported singles from the $60^{\prime} \mathrm{s} / 70^{\prime} \mathrm{s} / 80^{\prime} \mathrm{s}$.

* Open Mon. to Fri. 9 am to $5.30 \mathrm{pm}$

* Open to the public all year round. 

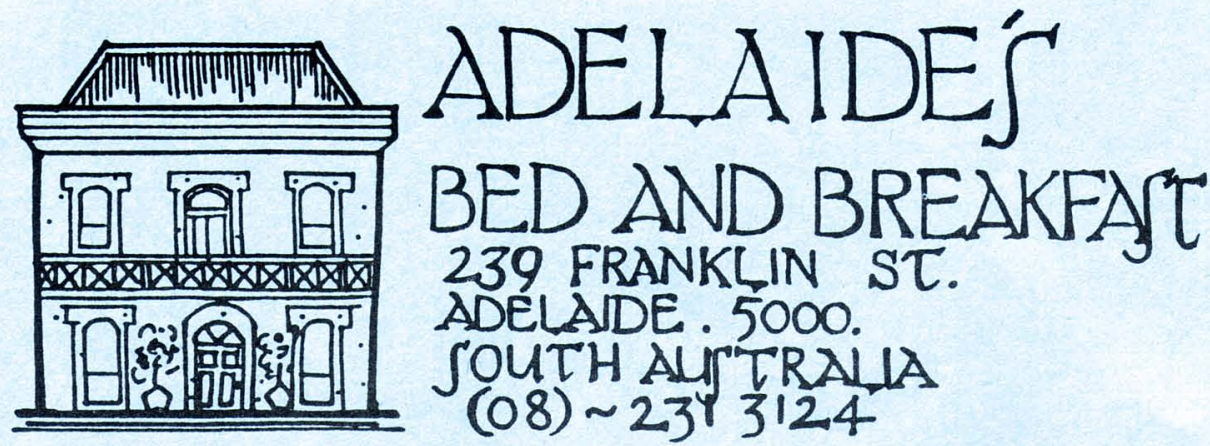

239 FRANKLIN ST.

ADELAIDE. 5000.

SOUTH AUT'TRALIA

(08) 23 3124

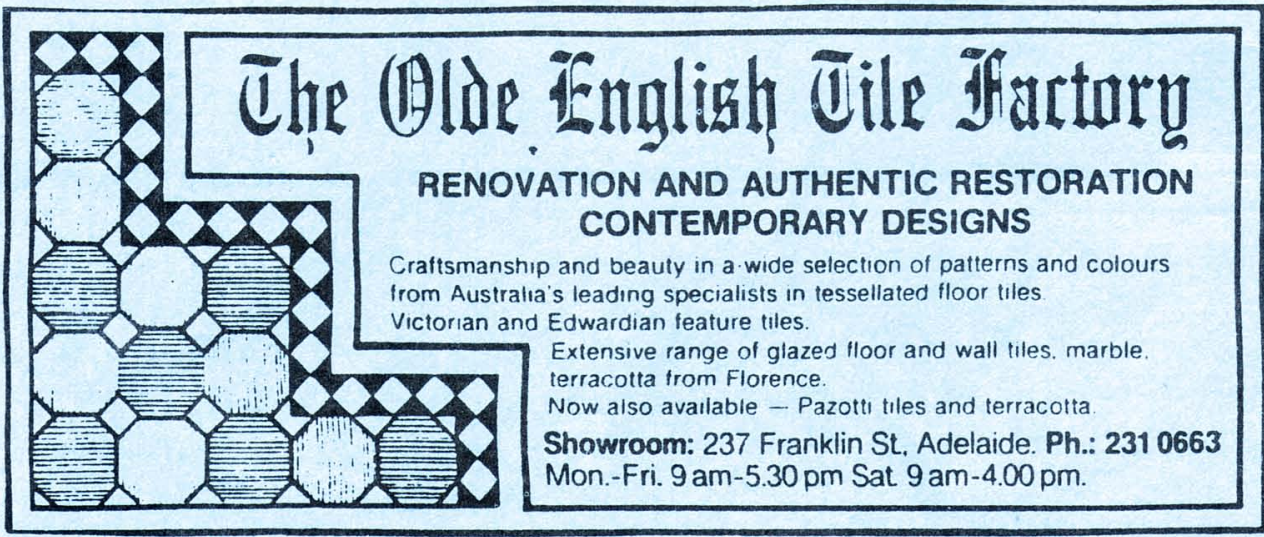

The STATE BANK OF SOUTH AUSTRALIA

is proud to be associated with the students of The Centre For The Performing Arts

Leaders in HIGH INTEREST

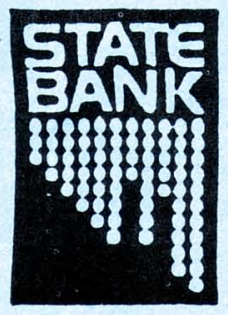

DIRECT CREDIT

EASYBANK CARD

BANKCARD

CHEQUE BOOKS

EASYLOANS

HOME FINANCE

Branch located on University grounds Level 3, First Floor, Union Building (Overlooking Barr-Smith Lawns) 


\section{ST,}

8

Specialists in Classic Athenian Dishes Vegetarian, Seafood and steaks

\section{ENJOY THE PANORAMIC VIEW}

$$
\text { FROM THE BALCUNY }
$$

3

- FRUM THE BALCONY

10 Jetty Rd, GLENELG. (upstairs)

reservations telephone....295

How many Public Relations Consultancies would bother to help sponsor a University Revue?

Or even know enough about Adelaide to know it's on?

\section{JUST ONE.}

H ICHELS WARREN FUELIC RELATIONS 185 Melbourne Street, North Adelaide 5006. Phone 2672822 Branch Offices in Sydney, Darwin and Melbourne. 


\section{Acknowledgements}

\section{THEATRE EXCHANGE}

MAGILL S.A.C.A.E. DRAMA DEPARTMENT

CARCLEW YOUTH PERFORMING ARTS

STATE OPERA THEATRE WORKSHOP

ADELAIDE UNIVERSITY FENCING CLUB

ADELAIDE UNIVERSITY, UNION HALL

ADELAIDE UNIVERSITY UNION

SOUTH AUSTRALIAN POLICE FORCE

CASTLE BACON

CADBURY CHOCOLATE

SUNFOODS CHEESE

CRYSTAL SPRINGS

AMSCOL

SUN-UP MILDURA

HARDNIGHTS PTY. LTD.

RICCA COFFEE

ROSSI SMALLGOODS

NIBBLES NUTS

BLACK FOREST CONTINENTAL CAKES

AMNESTY INTERNATIONAL

TIP TOP BAKERS

ARNOTTS BISCUITS

MONA LISA

HORST'S

COOPERS BREWERY

S.A. BREWING COMPANY

MANOS POULTRY INDUSTRIES

BUDGET CHAUFFEUR DRIVE

COLLEGIATE SCHOOL OF ST. PETER.

ECKERSLEY'S

Phil Heaton

University Theatre Guild 